\title{
新型乾燥装置の内部流動について
}

\author{
清田正徳 $^{1, \dagger}$ ，福富純一郎 ${ }^{1}$, 西 健織 $^{1}$, 寺島紀男 ${ }^{2}$ \\ ${ }^{1}$ 徳島大学大学院ソシオテクノサイエンス研究部, ${ }^{2}$ 株式会社マルミ
}

\section{Internal Flow of a New Type Drying Equipment}

\author{
Masanori KIYOTA $^{1, \dagger}$, Junichiro FUKUTOMI ${ }^{1}$, Takeshi NISHI ${ }^{1}$ and Norio TERASHIMA ${ }^{2}$ \\ ${ }^{1}$ Institute of Technology and Science, Tokushima University, 2-1 Minami-jyosanjima, Tokushima, 770-8506, Japan \\ ${ }^{2}$ Marumi Corporation, 230-1, Hanamen, Satoura, Naruto, Tokushima 772-0021, Japan
}

\begin{abstract}
The flow conditions of a new dryer for by-product of tofu proposed in the previous paper are examined. Its drying capacity is relatively small and to know the internal flow is necessary to develop larger capacity machines. Firstly, the interior of drying drum and classifying chamber were observed using high speed video. Wet materials returning from upper chamber are colliding with the materials and ceramic balls moving along the surface of the drying drum entrained in the hot air and dispersed. In the classifying chamber counterclockwise circulating flows are formed. Then numerical simulation was carried out for the flow of this dryer using FLUENT. Necessary nodes were about 800,000 to describe the whole machine. Obtained path lines are almost consistent with the video images showing the validity of the simulation method. To get the suitable geometry for 5 times larger machine, flow conditions were compared for three types of geometry of the entrance to classifying chamber and the best geometry was determined. The chamber height was then determined so that the velocities at the ceiling are below $3 \mathrm{~m} / \mathrm{s}$ to avoid adhesion of the wet materials to the wall. Based on the obtained results $300 \mathrm{~kg} / \mathrm{h}$ machine was build and it was successfully operated.
\end{abstract}

Keywords: Waste Disposal, Drying Drum, Ceramics Ball, Internal Flow, Numerical Simulation

\section{1. 緒言}

豆腐の製造時には扔から $[1,2]$ が副産物として発生 し，この処理が問題となっている．単に焼却するので はなく，これを乾燥し，得られる粉末を食材として利 用する事が考えられている。 しかし，乾燥させようと すると焦げ付きが生じてしまうなどの問題があり，適 用できる乾燥器がなかった $[3,5]$ ．これらを解決する方 法として，セラミックボールを封入した乾燥室をもつ, 新しいおからの乾燥器を開発し, 前報ではその性能に ついての検討をした [6]. 現在の処理能力は比較的小さ いので，産業用として利用するためには大容量化する 必要がある。そのためには，内部の流動状況について 十分に把握する必要がある。爷こで現行の乾燥器の内 部の流動の観察をするとともに，計算機を用いた数值

(受付 2008 年 5 月 24 日, 受理 2008 年 11 月 7 日)

1 ₹ 770-8506 徳島県徳島市南常三島町 2-1

2 ₹ 772-0021 徳島県鳴門市里浦町字花面 230-1

$\dagger$ Fax: 088-656-9082, E-mail:kiyota@me.tokushima-u.ac.jp
シミュレーションにより流れを求めて，これと比較検 討した。 さらに, 乾燥器の処理量を増やすために大型 化する目的で，寸法を大きくした際の流れの様子を調 べることによって，最適な形状寸法を求めるための考 察を行った.

\section{2. 乾燥器内の流れ}

\section{1 内部の観察}

前報で述べた $50 \mathrm{~kg} / \mathrm{h}$ の处理能力をもつ乾燥器に打 からを実際に投入して乾燥作業をしている状態での流 れの様子を把握するために観察を行った。乾燥ドラム と分級チャンバーの側壁に耐熱ガラス製の空を作り, 内部を見えるようにした，全負荷での運転状態をFig. 1 に示す．左が乾燥ドラムで右が分級チャンバーである. ドラム内全体におからが充満し旋回しているのがわか る.またチャンバー内では上ほど薄く乾燥が進んでい ること，右側壁を打からが上昇し左上方に乾燥した粉 末が流出していることがわかる．しかしながら，打か 
らに遮られて内部の詳細はほとんどわからない。そこ で打からの投入量を減らして，高速ビデオカメラで内

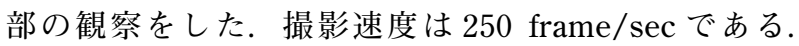
Fig. 2 はその一部を示したもので，時間経過の順に番号 をつけてある。のでき空の径は $230 \mathrm{~mm}$ でドラム径 400 $\mathrm{mm}$ に比べて小さく, ドラムの周辺部は見えていない. また，右上部に投入口，右下に熱風の吹き出し口があ るがこれらも視野外となっている．熱風はちょうどこ の空の取付フランジの陰になっている部分より外側を 流れて打り，内部には画面全体に右回りの旋回流が形 成されている．画面右下部に空フランジに沿って白い 部分が移動しているが，これは投入された扔からであ り,熱風により運ばれている. また画面左側においては,

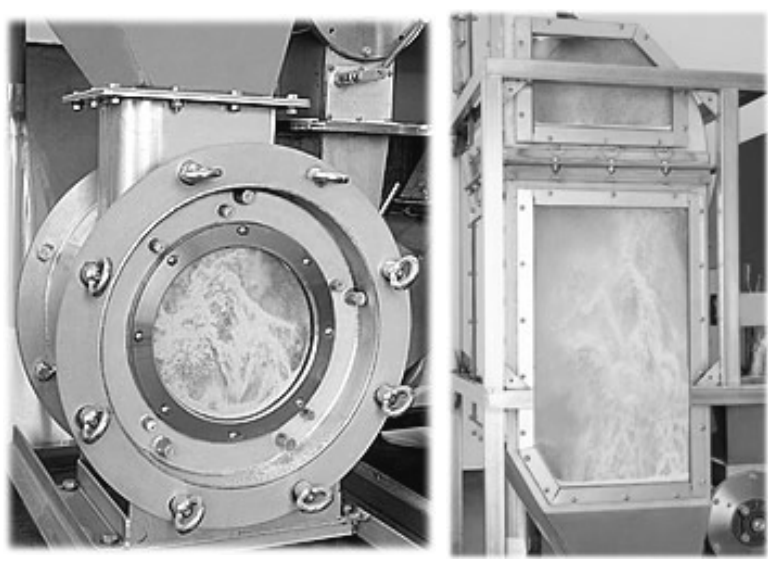

Fig. 1 Pictures of operating conditions.
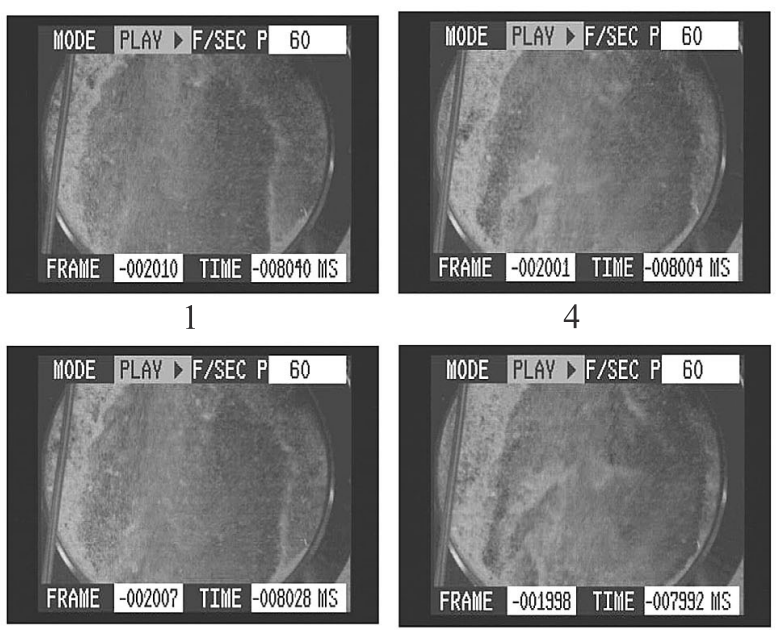

2

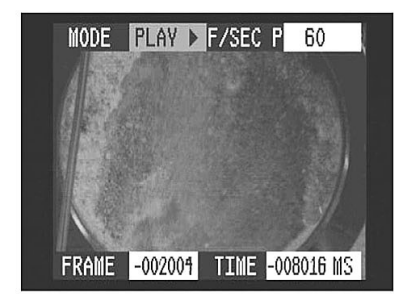

3

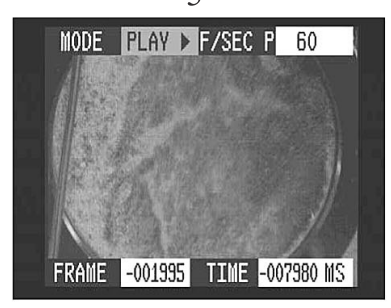

6

Fig. 2 High speed images of the flow in the drum.
おからが流れ落ちているが，これは上部チャンバーよ り戻ってくる扔からである，熱風の速度は，空に接し た部分では空の影響で減速される，乾燥の終わってい ない扔からは比較的重いため, この速度の遅い空際部 に集まるように落下してくる，このドラム壁に沿って 落ちてくる扔からに，右から来る熱風が画面の左下で 当たって上方に巻き上げられている．1でも吹き上げて いるが， $3 ， 4$ でよりはっきりとわかる. 熱風によって 運ばれているおからと落ちてくる扔からが衝突して，5 と 6 では画面全体に大きく吹き上げられている。 また, 落ちてくる扔からと巻き上げられた扔からが当たって 向きが変わりつつある。これらには写っていないが, ボールも巻き上げられて打り，ボールが含まれている ためより強く粉砕されていると考えられる. 白く写っ ている部分はまだ比較的大きくドラム内に残り旋回す るが，大半は粉末に近い状態になって高速流れの乗っ て上のチャンバーに運ばれている。打扎よそこのよう な状態が繰り返されているものと考えられる.

\section{2 数值シミュレーション}

観察した流机と比較するために，市販の汎用熱流体 解析ソフトFLUENT 6.2 を用いて流れのシミュレー ションを行った。計算領域は Fig. 3 に示すように乾燥 ドラム入口から分級チャンバーを経てサイクロン出口 までの全領域である。計算格子は全領域において非構 造四面体格子を用いており, 格子数は約 80 万である. 乱流モデルとして標準 $\mathrm{k}-\varepsilon$ モデルを使用している．こ の中で用いられているパラメターの値を Table 1 に示

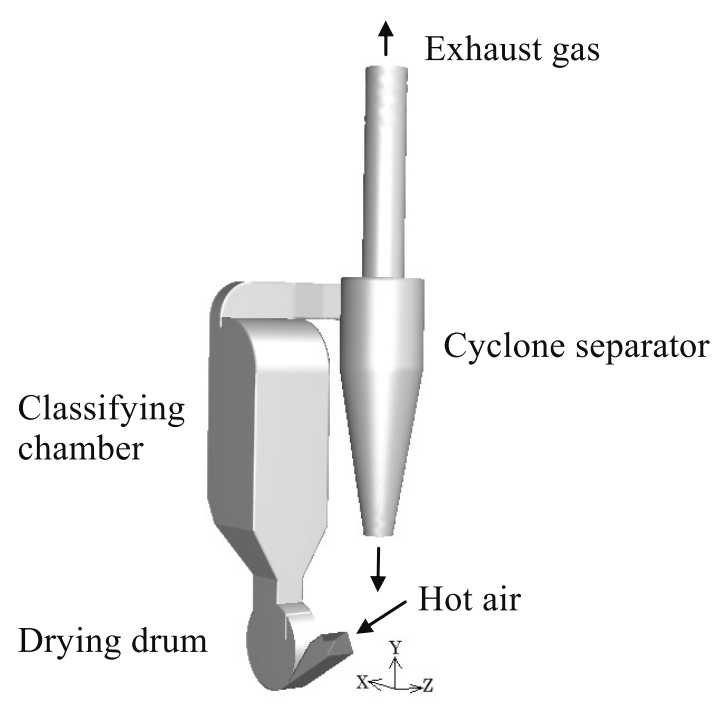

Fig. 3 Calculation area.

Table 1 Parameters used in the $\mathrm{k}-\varepsilon$ model.

\begin{tabular}{ccccc}
\hline $\mathrm{C}_{\mu}$ & $\sigma_{\kappa}$ & $\sigma_{\varepsilon}$ & $\sigma_{\varepsilon 1}$ & $\mathrm{C}_{\varepsilon 2}$ \\
\hline 0.09 & 1.0 & 1.3 & 1.44 & 1.92 \\
\hline
\end{tabular}



動させた軌跡をたどった流跡線である。

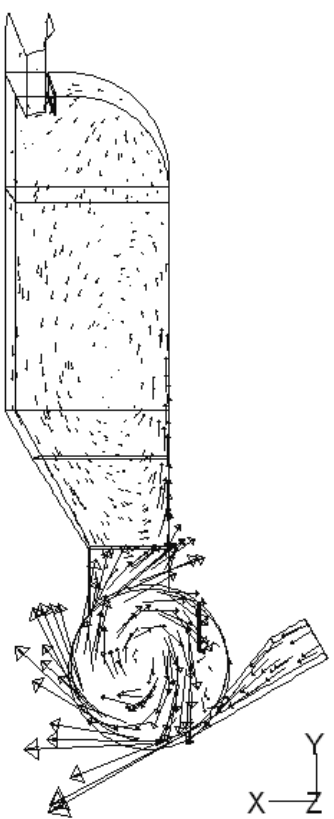

(a) Velocity vectors
す。境界条件のうち，乾燥ドラムへの熱風の入口速度 は $10 \mathrm{~m} / \mathrm{s}$ とした。乾燥を終えた気体はサイクロン分離 器の上部と下部より流出するので，ここでの圧力は大 気压となる。したがって，サイクロン出口の压力を 0 $\mathrm{Pa}$ と指定した。扔からの投入口は計算領域には加えて いない。また执からなどの被乾燥物，セラミックボー ルも加えていない。また熱風は近似的に空気として計 算した。シミュレーションによって得られた結果を Fig. 4 に示す. 乾燥器を $z$ 軸方向の手前の方からから見 た場合の立体図として表示してある。Fig.4(a) は奥行 き方向 $(z$ 軸方向 $)$ の中央位置の垂直断面上の速度べク トルである。ベクトルの長さは入口速度を基準として これに比例して描いてある。また，Fig. 4(b) は同じ垂 直断面内に質量のない粒子を配置し，流れに乗って移

まず乾燥ドラム内の流れを見てみる。ドラムへの入 口部はノズルになっており，このノズルで絞られて最 大流速は $95 \mathrm{~m} / \mathrm{s}$ になっている。この噴流がドラムに対 して接線方向に流入し，外壁に沿って時計回りに流れ， 上昇口を通って上方に流出する。この流れによってド ラム内部には旋回流が生じている。これは Fig. 1 ない しは Fig. 2 の写真によってもわかる. Fig. 4(b) の流跡 線を見ると，この旋回流部とドラムの壁との間は狭く， 高速気流はこの狭い部分に集中して流れていることが わかる. Fig. 2 に扔いても空から上端が一部見える程度 でこの気流部は狭くなっていると考えられる．右上の じゃま板の右側には逆回りの旋回流が生じている.こ のじゃま板の位置により旋回流の位置が変わる。実機

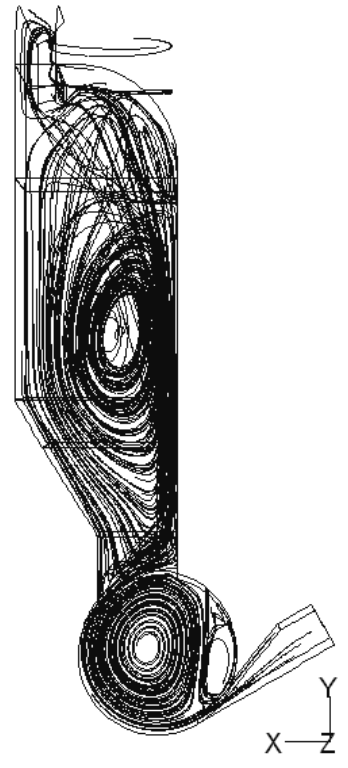

(b) Path lines
では，このじゃま板の右側の部分に被乾燥物を送り込 むロータリーフィーダーの開口部があり，拈からが投 入されている。

気流はドラムを出ると，チャンバー右側の壁に沿っ て上昇する流れとなる．Fig．4(a) のべクトル网による と，チャンバー内の気流の速度はドラム内よりもかな り遅い。ドラム出口では高速で $20 \mathrm{~m} / \mathrm{s}$ 程度である. 気 流はチャンバーの右側壁に沿って減速しながら垂直上 向きに流れ，チャンバー上部では $3 \mathrm{~m} / \mathrm{s}$ 以下にまで減 速されている. Fig. 4(b) の流跡線よりチャンバー内の 流れを見ると，右側壁に沿った速い流れと左回りの大 きな旋回流ができていることがわかる．流れは奥行き 方向に一様でなく，ドラムを出た速度の速い粒子は壁 際を上昇するが，一部は広がりながら上昇する。右下 から斜めに左上の出口に至る流跡線がそれである。上 部に達した流れは一部は出口から流出し，残りは下降 して左回りの大きな旋回流になる。また，上部では $\mathrm{x}$ 軸方向の軸まわりに旋回をしながら出口方向に向かつ て流れて扣り，罒の上部にらせん状の流跡線が見えて いる。これをたどると流出するものと，下降するもの とがある。下降したものは下部で噴流の影響で再び上 昇して比較的小さな左回りの旋回流を形成している. 下部の旋回流の上に小さな外から中へと巻き込む旋回 流れができていることになる。

チャンバー内の垂直断面内の流れを見るために，横 からスリット光を入れて高速ビデオ撮影した. Fig. 5 は その1コマである。明らかに，チャンバーの右側壁近 傍の上向きの流速が非常に速く，左側壁近傍の下降流 も速いが，チャンバー中央部の流速は遅く，チャンバー 内では反時計回りの旋回流が生じている様子がわかる. 被乾燥物の動きは, 数值シミュレーション結果の流跡 線に良く一致しており，被乾燥物が気流によって運ば れる様子が捉えられている.

チャンバー入口の Fig. 6 に示した位置に熱線風速計 を設置して風速の測定を行った。この速度はy 方向の 速度成分となる。得られた速度分布と同位置での数值

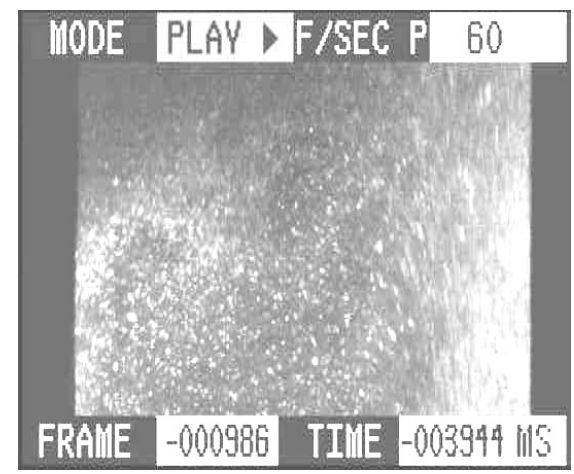

Fig. 4 Internal flow of $50 \mathrm{~kg} / \mathrm{h}$ dryer.
Fig. 5 Flow in chamber. 


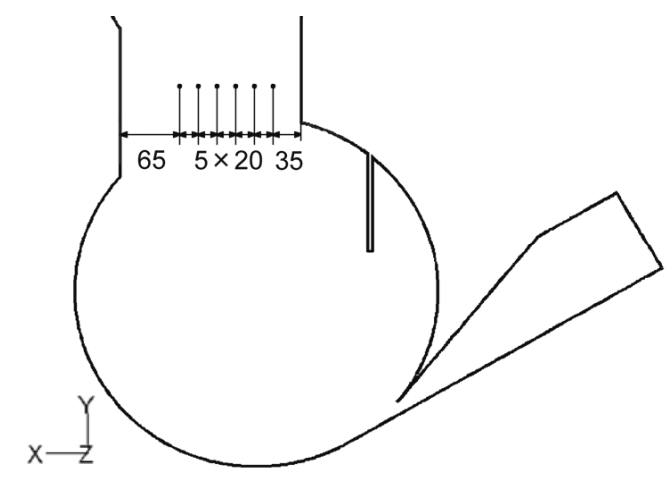

Fig. 6 Positions of velocity measurement.

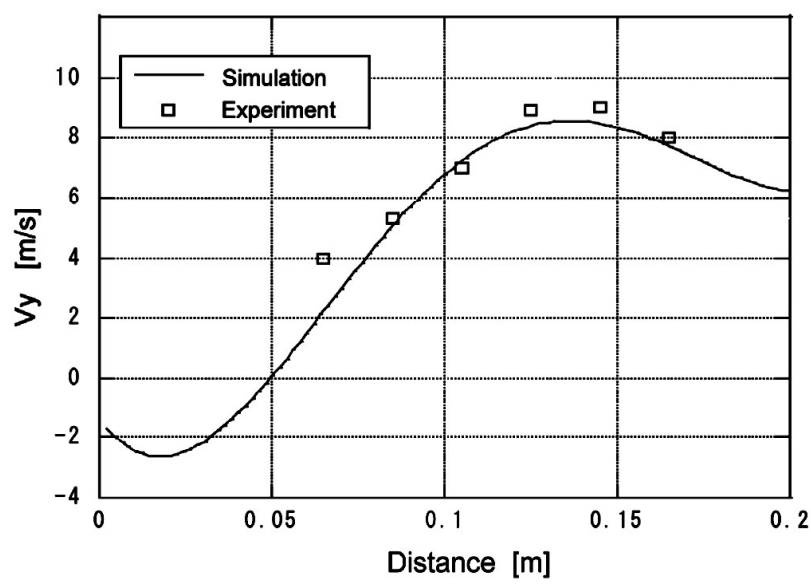

Fig. 7 Velocity in y direction.

シミュレーションによる速度分布を比較したのが Fig. 7 である。速度が最大となる位置は右側壁より約 $1 / 3$ の 位置であり，分布形状，值ともよく一致していること がわかる.またシミュレーションでは左壁より $1 / 4$ の 部分では速度が負になっておりチャンバーからドラム への逆流が生じていることがわかる．実測結果では実 験装置の都合上，この逆流している領域の測定データ は得られなかったが，それ以外では実験值と計算值は ほぼ一致している。この部分は乾燥しきれなかった重 い被乾燥物がチャンバー壁に堆積せずに，乾燥ドラム に戻ることになり乾燥作業に打いては有益であると考 えられる。このようにドラム内およびチャンバー内に おいて流れのよどみ領域はなく流れはスムーズであり， 被乾燥物が滞留するところはないと考えられる.

ところで扔からやラミックボールなどを加えて計 算はしているわけではない. しかし燃焼ガス流量に比 べておからなどの添加量が少ないためこれらを無視し ても比較的近い結果が得られたものと考えられる.

\section{3. 大型機の開発}

前報で提案した装置を用いて実際に運転してみると
$50 \mathrm{~kg} / \mathrm{h}$ の処理量では良好に運転が可能であった。 しか し，産業用に使うためには，処理量をさらに5〜10 倍 程度にまで増大する必要がある。最も簡単に大型化す るには，側面から見た形状は変更せずその厚さだけを 厚くすることが考えられるが，この方法では装置が大 きくなってしまう。これとは異なった大型化について 考えることにする.そこで現行機の 5 倍の処理量をも つ場合についての検討をシミュレーションにより行う. 基本的な寸法として, 乾燥ドラムの直径については, 現状機（Fig. 1）の $50 \mathrm{~kg} / \mathrm{h}$ タイプでは $400 \mathrm{~mm}$ であっ たが，これを $500 \mathrm{~mm}$ とする。また上部のチャンバー については, 水平断面の寸法を $1000 \mathrm{~mm} \times 1000 \mathrm{~mm}$, 高さは $3340 \mathrm{~mm}$ とする. 熱風入口部の断面積は現行機 の約 4 倍とした。乾燥量が 5 倍なので熱風量は 5 倍必 要になる，そこで，熱風の入口速度を $13 \mathrm{~m} / \mathrm{s}$ として計 算する. チャンバー入口の位置と寸法は，チャンバー 内の流机に大きな影響を及ぼす，そこで，Fig. 8 に示す ような 3 種類のチャンバー入口形状について考える. ドラム中心を通る直線に対して左側に $188 \mathrm{~mm}$ 右側に $62 \mathrm{~mm}$ とする場合を A タイプ，188 $\mathrm{mm}$ と $100 \mathrm{~mm}$ す る場合を $\mathrm{B}$ タイプ，200 $\mathrm{mm}$ と $100 \mathrm{~mm}$ する場合を C タイプとする.入口部の幅は $\mathrm{A}$ タイプは $250 \mathrm{~mm}, \mathrm{~B}$ タ イプは $288 \mathrm{~mm}, \mathrm{C}$ タイプは $300 \mathrm{~m}$ の順に広げてある. これらの奥行きは全て $500 \mathrm{~mm}$ とする。これらについ て流れの様子を比較する．奥行き方向の中央位置での 垂直断面の速度べクトル分布を Fig. 9 に，流跡線を Fig. 10 に示す. Fig. 9 の入口外部に入口速度べクトル を基準べクトルとして付加してある. ドラム内におい てはドラム内壁に沿って流れた後，Aタイプ，Bタイ プではチャンバー右側壁に向かうが，Cタイプではチャ ンバー左側壁に沿って流出しており, 全く流れが異なっ ている．またドラム内の旋回流は A と B はほぼ同じで あるが，Cは大きくチャンバー外に伸びている．白抜 き矢印で示したドラム出口部の流跡線を見ると，ここ での速度は $\mathrm{A}$ が最も速いためチャンバーからの逆流が A ではほとんど起きていない.これに対して Cでは右 側に逆流がありその先端がドラム内部にまで達してい る. Bでは左半分に逆流部があり，通路部の内部にま で及んでいる。

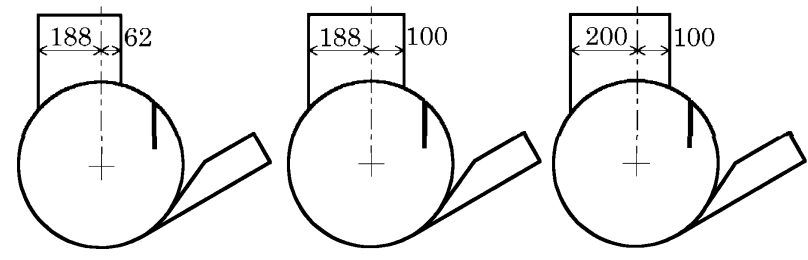
(a) Type A
(b) Type B
(c) Type C

Fig. 8 Variation of chamber inlet dimensions. 


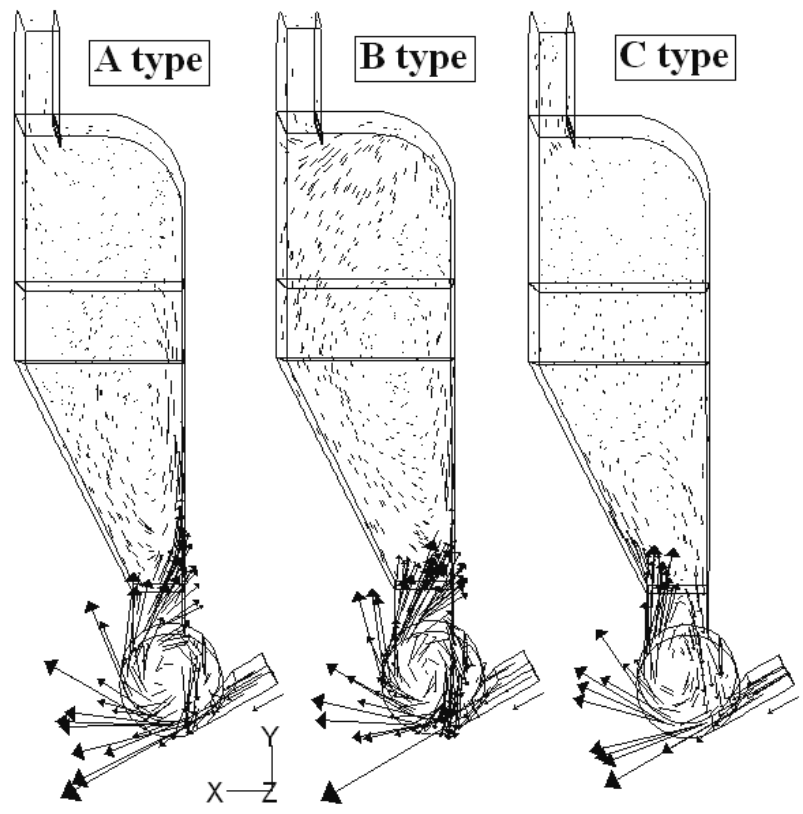

Fig. 9 Comparison of velocity vectors.

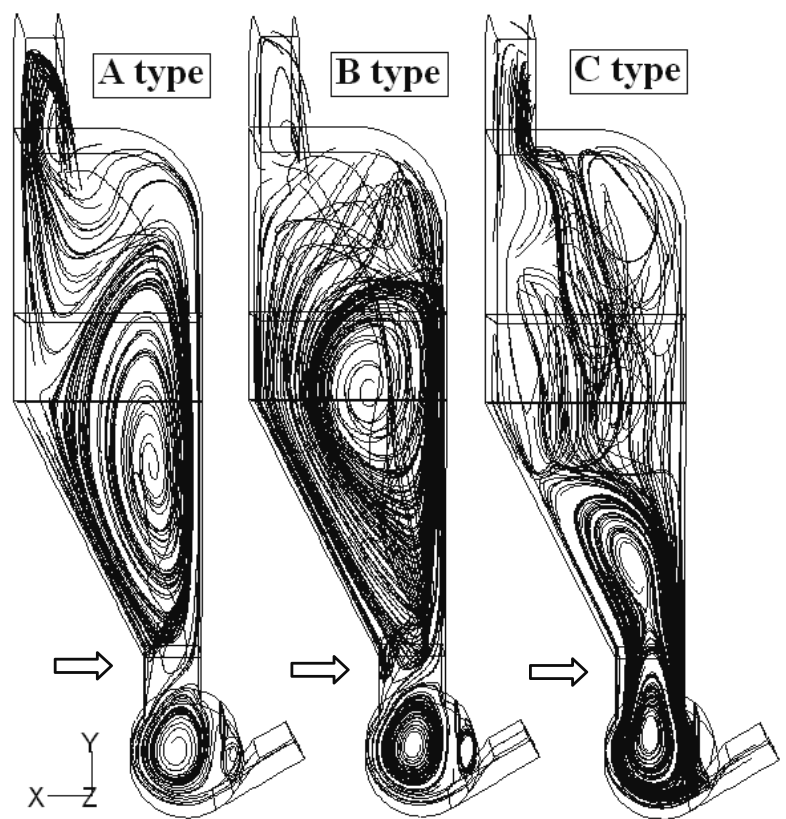

Fig. 10 Comparison of path lines.

チャンバー内の流れは, A タイプ, B タイプともにチャ ンバー入口で流速 $20 \mathrm{~m} / \mathrm{s} \sim 30 \mathrm{~m} / \mathrm{s}$ で流入しチャンバー の右側壁に沿って減速し垂直上向きに流れ，天井上部 に取り付けてあるじゃま板にあたり，一部はこれを乗 り越えてサイクロン部に向かう流れとなるが，残りは 下方に向かいチャンバー左側壁に沿って下降して流れ， 反時計回りの旋回流が形成される。Cタイプでは流れ が左側壁に沿って流れ，そのまま出口へ向かう流れと 右側壁に沿って下降する流れに分かれ，チャンバー下 部で時計回りの循環流が形成される。 $50 \mathrm{~kg} / \mathrm{h}$ 機の流跡
線と比較してみると A タイプと B タイプはほぼこれと 近い流れになっているが，Cタイプは明らかにこれと は異なっている。また，A タイプでは旋回流の奥行き 方向の変化が少ない。 そのため旋回流の上部域の流れ も2 次元的であり，速度も遅くなって打り，よどんで いるように見える，B タイプでは旋回流が奥行き方向 に変化しているため，旋回流の上部の流れが 2 次元的 でなく $\mathrm{x}$ 軸方向の軸回りに旋回する流れが生じており. $50 \mathrm{~kg} / \mathrm{h}$ 機の流跡線に最も似ている. また大きな循環流 の中心が A タイプの方が B タイプより下方にあり，循 環流の大きさが小さくスペースがむだになっている，B タイプの方がより好ましい循環流が形成されているこ とがわかる。しかし，B タイプにおいては，チャンバー 天井付近の速度が大きく, 被乾燥物の付着が考えられる。

そこで，Bタイプのチャンバーに抏いてその平行部 を $500 \mathrm{~mm}$ 長くして全体の高さを高くすることを考え た。これを Dタイプとする. Dタイプの速度べクトル を Fig. 11(a) に，流跡線を Fig. 11(b) に示す. ドラム内 の速度べクトルを比較してみると，Dタイプでは $\mathrm{B}$ タ イプに比べて天井近くでのべクトルの長さが短くなっ ていることがわかる. B タイプでは約 $6 \mathrm{~m} / \mathrm{s}$ 程度の速 度をもつが，Dタイプでは $3 \mathrm{~m} / \mathrm{s}$ 以下になっている. 経験的に， $3 \mathrm{~m} / \mathrm{s}$ であれば扔からは壁に付着しない. 流跡線を見てみるとDタイプにおいては，その旋回流 の中心は B タイプよりもさらに上方に移動しており， また B タイプよりもさらに大きな旋回流が形成されて

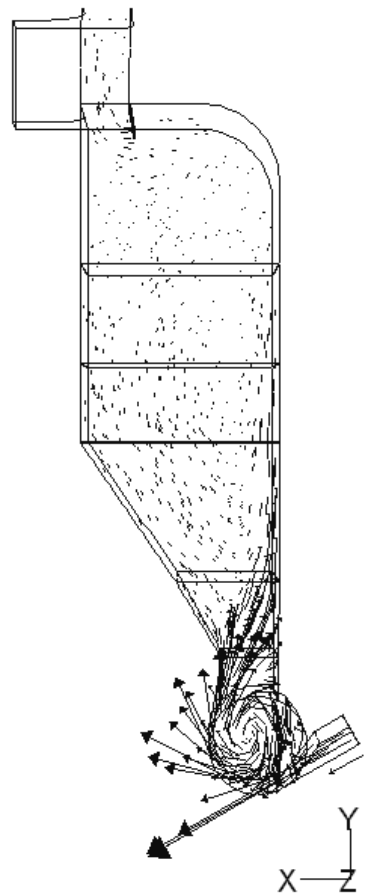

(a) Velocity vectors

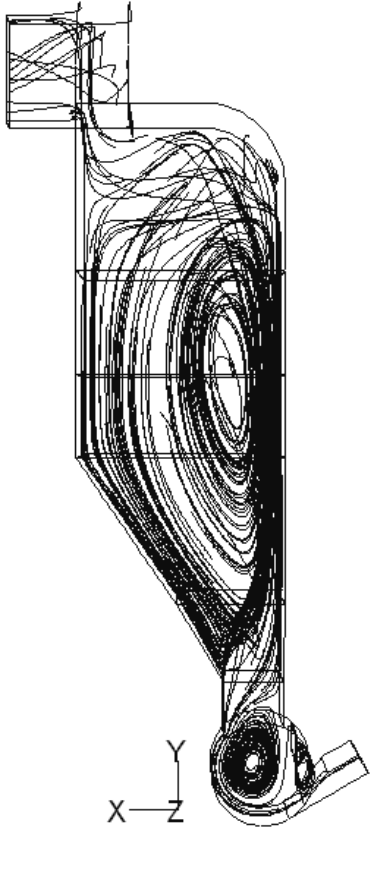

(b) Path lines
Fig. 11 Internal flow of D type. 
いる.この旋回流は奥行き方向に一様でなく，これら の上の流れも 3 次元的な流れという特徴もみられる. このように，Dタイプではチャンバー右側壁上部を沿 う流速は $3 \mathrm{~m} / \mathrm{s}$ 以下まで減速され，しかも大きな循環 流が形成されているので， $50 \mathrm{~kg} / \mathrm{h}$ 機と同じような乾燥 に適した流れとなっていると考えられる.

これらに基づいて試作された乾燥器を用いて実際に 運転してみると，拉よそ $300 \mathrm{~kg} / \mathrm{h}$ 程度まで運転可能で あり，得られる乾燥おからの状態も良好であることが わかった。

\section{4. 結}

新しい乾燥器の大容量化をするための指針を得るた めに，流れの観察と解析を行った。 その結果，以下の ことがわかった。

(1) 処理量 $50 \mathrm{~kg} / \mathrm{h}$ の現行機の乾燥ドラム内には, ド ラムの内壁に沿って高速気流部があり，その内側に右 回りの循環流が形成されている。またじゃま板を挟ん で反対側には左回りの循環流ができている。

(2) 同じく分級チャンバー内には左回りの大きな循環 流が形成されている.

(3) 現行機の流動についての数值シミュレーション結 果は, 実際の乾燥物の画像や流速分布の測定值と良く 対応しており，シミュレーションは有効である.

（4）乾燥ドラムを $5 / 4$ 倍にして，処理量を 5 倍とする ためには，チャンバー入口を比較した 3 種類の内 $\mathrm{B}$ タ イプとし，さらにチャンバー高さを $500 \mathrm{~mm}$ 高くする と良いことがわかった。

\section{引用 文 献}

[1] "Tables of ingredients of foods (Syokuhin Seibun Hyou)”, Kagawa Nutrition University ed., Kagawa Nutrition University Publishing Division, Japan, 2003, pp.
118-119.

[2] "Handbook of food engineering (Syokuhin Kougaku Hando Bukku)”, Japan Society for Food Engineering ed., Asakura Syoten, Tokyo, Japan, 2006, pp.452-455.

[3] A. Kubota; "Drying equipments, 2nd edition (Kansou Souchi)”, The Energy Conservation Center, Japan, 2004.

[4] R. Kirie; "Drying, 4th edition(Kansou)", Kagaku Kogyo Sya, Tokyo, Japan, 2002.

[5] M. Nakamura, Y. Tatemoto; "Studying drying technology from the basics (Kiso Kara Manabu Kansou Gijyutsu)", Kogyo Chosakai, Tokyo, Japan, 2005.

[6] M. Kiyota, J. Fukutomi, T. Nishi, N. Terashima, Drying performance of a new type drying equipment (in Japanese), Japan J. Food. Eng., 9, 303-309 (2008).

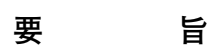

前報で提案した $50 \mathrm{~kg} / \mathrm{h}$ の処理能力をもつ乾燥器の 内部の流れの観測と解析をまず行った。高速度ビデオ により，乾燥ドラム内での扔からの分散状況や，分級 チャンバー内の左回りの大きな旋回流が観測できた. 解析により，ドラム内には内壁に沿って高速気流部が あり，その内側に右回りの循環流が形成され，じゃま 板の反対側には左回りの循環流があること，また，チャ ンバー内には左回りの大きな循環流があることが確認 できた。解析結果は，実際の内部流机の画像や流速分 布の測定值と良く対応しており，本解析は有効である ことがわかる。そこでこれを用いて，乾燥ドラムを $5 / 4$ 倍にして，処理量を 5 倍とするためには，チャンバー 入口を比較した 3 種類の内 B タイプとし，さらにチャ ンバー高さを $500 \mathrm{~mm}$ 高くするとよいことがわかった. 得られた結果に基づいて試作した乾燥器により，およ そ $300 \mathrm{~kg} / \mathrm{h}$ 程度まで良好におからを乾燥できることが わかった. 